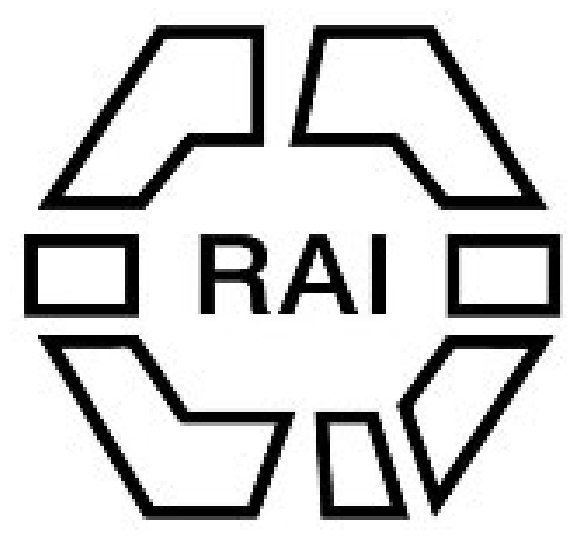

On an Ancient British Settlement Excavated Near Rushmore, Salisbury Author(s): Pitt-Rivers

Source: The Journal of the Anthropological Institute of Great Britain and Ireland, Vol. 17 (1888), pp. 190-201

Published by: Royal Anthropological Institute of Great Britain and Ireland

Stable URL: http://www.jstor.org/stable/2841928

Accessed: 15/06/2014 21:18

Your use of the JSTOR archive indicates your acceptance of the Terms \& Conditions of Use, available at http://www.jstor.org/page/info/about/policies/terms.jsp

JSTOR is a not-for-profit service that helps scholars, researchers, and students discover, use, and build upon a wide range of content in a trusted digital archive. We use information technology and tools to increase productivity and facilitate new forms of scholarship. For more information about JSTOR, please contact support@jstor.org.

Royal Anthropological Institute of Great Britain and Ireland is collaborating with JSTOR to digitize, preserve and extend access to The Journal of the Anthropological Institute of Great Britain and Ireland. 
From the Societr.-Bulletin de la Société Impériale des Naturalistes de Moscou. 1886. No. 3.

Bulletin de la Société de Borda, Dax. 1887. Part 3.

From the Editor.-Nature. Nos. 920, 921.

- Science. No. 227.

The Photographic Times. Nos. 299, 300.

Revue d'Ethnographie. 1887. No. 1.

Lieut.-General Pitt-Rivers exhibited a series of very fine models illustrating his recent excavations in Cranborne Chase ; and read the following paper:-

\section{On an Ancient British Settlement Excavated near Rushmore, SAlisbury.}

By Lieut.-General PitT-Rivers, D.C.L., F.R.S., F.S.A., F.G.S., Vice-President Anthrop. Inst.

In my privately-printed 4to volume of "Excavations in Cranborne Chase," vol. I, relating to the excavations in the village on Woodcuts Common, ${ }^{1}$ I have described everything found there with the utmost detail, avoiding theory as much as possible, and desiring to make it a work of reference that could be relied upon for the forms of art of that period found in this neighbourhood. In collecting evidence from archæological works professing to be descriptive, I have often experienced the inconvenience of having to wade through a mass of speculative matter in order to pick out the facts, and I have endeavoured to avoid this error by tabulating the materials, and placing the illustrations of the objects in juxtaposition with the descriptions of them. This course, no doubt, detracts from the interest of the volume to the general public, but adds to its value to the working anthropologist and archæologist. But, in my Presidential Address to the meeting of the Archæological Institute at Salisbury, in 1887, I have enlarged a little, and shown the bearing of this discovery upon general questions.

The Romanised Britons have not, I think, been studied by anthropologists so much as they deserve. Whilst the stone and bronze age people have engrossed our attention, and we have little difficulty in speaking of their physical peculiarities or their arts, the Britons, as they were left after the withdrawal of

1 "Excavations in Cranborne Chase, near Rushmore, on the borders of Dorset and Wilts." By Lieutenant-General Pitt-Rivers, D.C.L., F.R.S., Vol. I. Printed privately, 1887. A copy of this work has been presented by the author to the Library of the Institute. 
the Roman Legions, remain a mystery to us, and afford scope for the widest divergence of opinion. Yet their influence upon the existing population of the country must have been far greater than that of the generations which preceded them. Although the late Celtic art and ornamentation, found sporadically in this country before the Roman Conquest, shows evidence of much taste and refinement, yet the three centuries of Roman occupation must be considered virtually to mark the first stages of civilisation in England, and the Briton before and after that period must have been, in many respects, a very different being. Whilst some have represented him as utterly degenerate after the Romans left, and to have been almost exterminated by the Saxons in the central and eastern part of the country, recent investigation has tended to modify this opinion considerably. There can be no doubt that we had a great and noble inheritance from Rome, and that much of it must have been passed on to us by the Britons who succeeded in inoculating their rude Saxon conquerors with what they had learnt from their old masters. It is even now believed by some that the language of the Romanised Britons was entirely Latin, and that the Celtic speech had to be reintroduced into Wales by tribes that had lived beyond the area of Roman influence in the north.

Much of this ignorance of the condition of the Britons at this time, arises, no doubt, from the difficulty of identifying their graves. A stone or a bronze age grave can be easily determined by the associated relics, but the Romans introduced so many auxiliaries and colonists from different parts of the world, that a skeleton found in association with Roman relics may be that of a native of any part of that wide region over which the Roman dominion extended. This gives additional interest to the study of the remains of people who inhabited the Wiltshire Downs in the western part of the country, in places that are remote from the Roman centres, in high and comparatively barren spots to which the aborigines are likely to have been driven by their conquerors, where the probability of finding the remains of the genuine Briton is much greater; and when we find in these places skeletons buried in pits in the villages which they inhabited, surrounded by the relics that they used in life, and the remains of their habitations, this serves still more surely to identify them as Britons; for it is unlikely that the Romans themselves, or their allies, should have paid so little attention to the remains of their dead as to throw them into pits with refuse, without any of the signs of decent burial.

Moreover, we find that those who were buried with any o 2 
signs of care were crouched up after the ancient manner of the Britons, but few having been found extended, and of these some of them buried beneath the little ramparts of the villages in such a way as to show that the latter had been thrown over them, and that the direction of the bodies was given to them by the lines of the raniparts, and the drains in which they were also found interred. All this proves them to be the remains of a subject rather than a dominant people, and the associated relics serve also to fix their age without difficulty. The pottery, of which immense quantities were found in fragments both in the pits and beneath the surface, some of it in a condition to be restored, was mostly British, and the pots resembled those found in settlements of the Roman age found elsewhere, especially in Dorsetshire. But with it were fragments of Samian of Roman manufacture, and the position of these undoubtedly Roman fragments showed that it was in use during the greater part, if not the whole, of the time of the occupation of the village. The Roman coins speak to the same effect, being of all dates from Caligula, A.D. 37, to Magnentius, A.D. $35 \%$, and they were continuous during the whole period with one considerable gap of fifty years extending from Clodius Albinus, A.D. 193, to Trebonianus Gallus, A.D. 253. No doubt many of the earlier coins were used up to a late date, and, therefore, afford no actual evidence of the duration of the period of occupation; but one special find, consisting of the remains of a box, the wood of which was found adhering to bronze ornaments and dolphin-shaped handles, appeared to have contained coins dating from Claudius, A.D. 41, to Claudius Gothicus, A.D. 270 , all of which, if forming the contents of the box, must have been in use at the same time. The village also produced four British silver uninscribed coins of the type which appear's, by Mr. Evans' work, to have been prevalent in this neighbourhood. These British coins may, probably, have been in use for some time after Roman occupation, but it is hardly likely they should have been employed up to the latest period, so that it seems probable the village must have been occupied early, as well as late, during the Roman era. Other circumstances point to the same conclusion. The little banks surrounding the village and its outworks, showed evidence of having been altered, and the excavations proved that, in some places, banks had been raised over spots where ditches previously existed. Such changes need not have taken centuries to develop themselves, but they prove continuity of occupation. The pits, of which ninety-five were found, were of slightly different shapes, some, about 11 feet deep, were in the form of a truncated cone, slightly larger at bottom than top, with the sides smoothly 
cut in the chalk, but in no case revetted. Others were quite cylindrical, and not more than 4 feet deep. Others had a plan in the form of two or three circles cutting into each other, suggesting side chambers or cupboards, yet suggesting also the possibility of one pit having been cut and filled up again before the others were made; for it is not evident why the circular form should have been so strictly adhered to in the case of side chambers or cupboards. The depths also of these united pits did not in many cases coincile. They were all filled to the top with earth and refuse, including fragments of pottery and the remains of lomesticated animals. In some places these collections of refuse looked as if it had been thrown in in a heap, but in other parts it was interspersed here and there as if it had been introduced in the earth with which the pits were filled up to the top so completely as to show no trace upon the surface before the excavations commenced. With the bones a few fragments of human skeletons were found occasionally, besides the entire skeletons of human beings which were thrown into some of the pits. Only one Roman coin was found in a pit, all the rest having been found whilst trenching the surface, which suggests the possibility of most of the pits having been filled up before coins came into general use in the village. One quarter of the village contained relics of superior quality to the other quarters. Here flat pieces of painted plàster showed that they occupied square shaped rooms ornamented in the interior, whilst in other parts of the village the fragments of clay found with the impression of interlaced sticks upon them, showed that they lived in houses made of dab and wattle similar to those which I have elsewhere described as having been found at Mount Caburn, near Lewes, and which were shown to be of the late Celtic period. In the rich quarter also were quantities of iron nails, which denoted that cut timber work was used in the houses, and these nails were deficient in the pits generally. Tiles-of Purbeck shale, with nail holes to fasten them by, were also found more f'equently in the rich quarter than elsewhere, and terra cotta "tegulæ" were also found there, but only in fragments and used as pavements, for which purpose these tiles were frequently employed elsewhere. The absence of "imbrices" which are a nccessary adjunct in the formation of a Roman tiled roof confirms the opinion that the roofs in the Romano-British village were not tiled in this way; although the fragments of the tiles showed that they had certainly been originally constructed for roofing; their use for a secondhand purpose conveys the impression of poverty, although too much stress must not be laid upon the circumstance. In forming a comparison between the relics found in the pits and those found just beneath the sur- 
face in places where there were no pits, and on the surface over the pits, what Mr. Pengelly has observed is perfectly true, that the surface must have been occupied at the same time as the the earliest pits, and must, therefore, contain some of the relics earliest dropped about in the village. But if we are to believe that the pits were filled up successively as they were abandoned and others dug to replace them, it is evident that those early filled up would no longer continue to be the receptacles for oljects in use during the later period of occupation, but would contain only the earliest things, whilst the surface would contain the things of all the periods. There is an object, therefore, in comparing the relative numbers of the better class of things found in the pits and on the surface. This has been done with great care, with the result that a much larger quantity of good things, and things of decidedly Roman construction, have been found on the surface than in the pits, although there is no certain evidence derivable from this source that the village was ever occupied before Roman times. On the other hand things of commoner use were more abundant in the pits. This may be accounted for partly by supposing that the village grew in wealth as it went on, and partly by supposing that the better things were more generally used in the rich quarter where timber built houses existed, and where the pits were scarcer, than in the poorer quarter where pits were more abundant. The value of the evidence bearing upon these points can only be understood by carefully studying the relic tables given in my volume and the deductions that are there made from them. It is always a mistake to expect positive and conclusive evidence from excavations of this nature; at the best, results can only be arrived at by a balance of probabilities and by recording all the finds with the utmost care.

The use of the pits cannot be determined with certainty, but there is reason to suppose that the majority of them were made to contain refuse, and that the habitations were on the surface near them. They resemble the pits found in British settlements of the late Celtic period such as Mount Caburn; so that the interior economy of the British villages must have remained unchanged in Roman times.

By careful measurement of all the animal bones and comparison with test animals, the height and length of which were measured before being killed, it appears that all the domesticated animals were small, except the pig, which was of nearly the same size as our own. The horse did not exceed 11 to 12 hands, and resembled the Exmoor pony in form. The short-horned ox, Bos longifrons, was about the size of an Alderney cow; the sheep. was small and long-legged, resembling those now found only on 
the Island of St. Kilda. The dog was of all sizes, from that of a large mastiff or retriever to a small terrier, and one bone of a Dachshound was also found. Tables of measurement and comparison with the test animals will, I hope, be given in my next volume, on the Excavations in the village of Rotherley, now in course of preparation. Professor Rolleston was paying attention to the subject of ancient domesticated breeds at the time of his death, and I hope to be able to lay the foundation for a careful study of the subject in my next volume. The horse, as well as the ox and sheep, was used for food. It is not certain that the dog was so used, though the number of detached bones of that animal found with the others rather implies that such was the case. On the other hand, one entire skeleton of a dog was found buried with a human skeleton in a grave. Roe deer was used for food in small quantities but not the red deer, although its horns were used for the handles of implements. No horns of fallow deer were found. Oysters were found in large numbers, as is usually the case in all villages of the Roman age. Three thousand and twenty-five of these shells were found in the village, but I omitted to count the number of upper and lower valves, until a large number had been destroyed. Of the one thousand eight hundred and seventy-three that then remained I found that nine hundred and sixteen were tops and nine hundred and fiftyseven bottorns, from which it is evident that they had been imported entire; the upper valves are more liable to destruction than the lower ones. No other mollusks were found, nor were land shells found in sufficient number to allow it to be supposed that snails were eaten. No specimen of Helix pomatia was discovered. Although it was evidently an outlying agricultural village, the people were not without refinement as attested by a number of bronze finger rings of Roman manufacture, set with glass and adapted to fingers of small size. The numerous bronze fibulæ found were all of Roman type, and two mosaic brooches of blue, red, and white pattern, were of the finest workmanship. As a rule, the pottery was of rude manufacture, but with that bottoms adapted to stand on tables. Some of the vessels had handles, but many of them were provided with loops for suspension, somewhat similar to those still used by Dorsetshire labourers in the fields, a form that is not uncommon amongst Roman remains in this neighbourhood. It appeared to be wheelturned, but subsequently smoothed over with striæ running in different directions so as to obliterate the marks of the wheel. One perfect Samian bowl with figures in relief was found in fragments and restored. Scarcely any fragments of the coarse British pottery, having large grains of quartz or shell in its composition, were found during the excavations. 
One of the most remarkable characteristics of the village was the extensive arrangements that had been made for drainage. Ditches 3 to 4 feet deep surrounded the village, and from these other deep drains led down hill and along the sides of the roads, leading to and from the village, implying probably a much greater rainfall than is experienced at the present time. The drains consisted of open ditches, no trace of conduits or faggots having been found in them.

The same conclusion as to the rainfall is borne out by the depth of the wells, two of which were found in the village, one 136 and the other 188 feet deep. At the bottom of the deeper one, the iron bands and handle of the Roman bucket were found, shewing that it had been used to obtain water, although it is now quite dry, and a diagram given in my volume showing the depths of the existing wells on the hill in comparison with the Roman ones, brings to light the fact that water was obtained in Roman times at a higher level than is the case at present. No doubt the destruction of the ancient forests and the drainage of the land has brought about this change, and the description of Britain by Pytheas as a "land of clouds and rain," must have well applied to the condition of the country at the time we are speaking of. Associated with the climate also must be considered several hypocausts found in the village. The use of some of them is doubtful, but one appears clearly to resemble a British copy of a Roman flue used for warming a room, made with flags of Purbeck shale instead of tiles, and shewing that the owner of the house must have become thoroughly imbued with Roman ideas of comfort. In one of these hypocausts a skeleton was found, which had been interred at the time it was filled up with earth. In one of the pits, the skeleton of a child about 12 years of age was found to have been killed by a sword cut on the back of the head, and it was thrown into the pit with two adults. Twenty-two skeletons of infants were also discovered in various parts of the excavations, the majority of which were new-born, reminding us of the Roman custom of burying young children under the eaves of the houses. By measuring several samples of ancient wheat found in the pits, it was found that the number of grains to the cubic inch, was the same as in wheat now grown at the same level. This differs from British and pre-Roman grain, which I found higher up on the hill, which shewed nearly twice as many grains to the cubic inch as wheat now grown near the same spot, from which it appears that the influence of Roman methods of husbandry had told upon the quality of the grain produced at the time of the occupation of this village.

On the feet of two of the skeletons iron hobnails, Roman 
fashion, were found. and on a third a quantity of similar nails covered the shin hones, some of which were corroded together at the heads, showing that probably they had served to arm leather greaves, with which the lower part of the legs had been covered.

This being the condition of the remains, and the probability of the inhabitants of the village being Britons of the Roman era being well attested, it is interesting to consider the physical peculiarities of the skeletons found thrown into the pits or otherwise buried within the village. All the skulls that could be restored have been carefully drawn in my volume, and the measurements of the skulls and of the bones of the skeletons are attached to the plates. The first thing that strikes one is their exceedingly small stature, $3 \frac{1}{2}$ inches lower than the estimated stature of small long-barrow people of this district, and this is the more remarkable because the only two bronze age skeletons that I have found in this neighbourhood are of the usual large stature of the bronze age folk. And the Saxons also which I found in the neighbouring cemetery at Winkelbury were of the usual comparatively large size of that people. Of fifteen skeletons found in the village of Woodcuts, the stature of thirteen could be estimated by the long bones, viz., seven males, average stature 5 feet 4.0 inches, and six females average stature, 4 feet 11.8 inches. The average stature of the males is increased by one skeleton, which, in the opinion of both Dr. Beddoe and Dr. Garson, who have examined them, has marked characteristics of Roman origin, and which is 3 inches taller than the tallest of the rest. He was also found in an extended position, and had a remarkably brachycephalic skull, the only one found in this village. If this skeleton were omitted it would reduce the average stature of the males by 0.7 inches, making it 5 feet 3.3 inches instead of 5 feet 4.0 inches, and the height of the tallest man 5 feet 4.8 inches instead of 5 feet $7 \cdot 8$ inches. It is all the more probable that this skeleton was exceptional in height from the fact that in the neighbouring Romano-British village of Rotherley, the description of which is now in course of preparation in a second 4to volume, the average height of eleven males has been found to be only 5 feet 1.3 inch and that of three females 4 feet 10.0 inches, proving the existence of a very short race inhabiting these villages at that time.

Including together the skeletons in the Woodcuts and Rotherley villages with the skeleton above mentioned, supposed to have Roman characteristics, and adding one other skeleton of the Roman-British period found in a pit in the neighbourbood, all being assumed on sufficient evidence to be Romano-Britons, the following is the result:-Males, eighteen, average stature, 5 feet $2 \cdot 6$ inches ; females, ten, average stature, 4 feet $10 \cdot 9$ inches. 
To what cause is this small stature to be attributed? To inheritance of the peculiarities of their long-barrow ancestors? If so, why should their stature have been still further reduced below the average of that people? To the drafting of the stronger portion of the males into the Roman legions abroad? Perhaps the comparatively large size of the females to which Mr. Galton has alluded may be taken to favour that view, or to the results of bad living and exposure, and to evils attendant upon slavery? Possibly the small size of all the other animals may be thought to have some bearing on the general effects of poverty; whilst on the other hand the large size of the grains of wheat, to which I have referred, above what was found to prevail in pre-Roman times, may be taken as evidence of the existence of an advanced state of agriculture in the small square fields which are to be traced in the neighbourhood of the villages.

In estimating the stature from all the long bones, Dr. Topinard's method, as given in his " Anthropologie Générale," has been strictly adhered to. I found that the difference of stature caused by the different methods of estimating the same skeleton by English physical anthropologists including Beddoe, Flower, Humphry, and Rolleston amounted to no less than 4 inches, a difference exceeding the average difference of stature of many European races, and therefore sufficient to invalidate any comparison that might be made from them. ${ }^{l}$ Without prejudice therefore to any of the systems advocated by those gentlemen, I have conformed to Dr. Topinard's rules for the sake of uniformity, and in this I am supported by Dr. Garson. But I would draw the attention of anthropologists to this important point. Questions of stature enter so largely into all racial speculations that a uniform system of estimating stature from the long bones is a matter of the most urgent necessity. The uniformity obtained by estimating from the different bones of the same skeleton appears to me to afford evidence, that the calculation is a reliable one if only the proper formula is used, and Dr. Topinard's method, even if it should not turn out to be quite the best, appears to me sufficiently reliable to serve as a generally accepted standard.

In estimating the cephalic index I have also used Dr. Topinard's rules. The glabello-occipital length has been made the chief basis of calculation, although the ophryo-occipital length has in all cases been given as well. The result for the Woodcuts skulls shows : one brachycephalic skull, that of the possible Roman above referred to, whose index is 822 ; seven mesalicephalic, ranging from 750 to 799 , and five dolichocephalic, rang-

' Prof. Flower's method accords very closely with Dr. Topinard's. 
ing from 714 to 746 . The prevalence of long skulls in the village is therefore very apparent, and this tallies with the subsequent excavations in Rotherley village, where, out of thirteen skulls measured, one only was brachycephalic, with an index of 826 ; three were mesaticephalic, ranging from 756 to 799 , including one, which, if the ophryo-occipital length had been taken, would have been included amongst the brachycephalic; six were dolichocephalic ranging from 702 to 743 , and three were hyperdolichocephalic ranging from 689 to 696 .

Including together the skeletons in the Woodcutsand Rotherley villages, all of which were Romano-Britons, the following is the result:-Brachycephalic, two; mesaticephalic, ten; dolichocephalic, eleven; hyperdolichocephalic, three.

In my address to the Archæological Institute at Salisbury ("Journ. Arch. Inst.," xliv, page 271), I have referred to the peculiarities of this district as an ancient ethnical frontier, and to the existence of a small dark race of people amongst the peasantry at the present time.

The practice of burying in the villages, which has been brought to light by my examination of two of them, affords good opportunities of studying the peculiarities of race in Roman times, and the number of these villages as yet unexplored appears to promise a rich harvest for future anthropological research.

\section{Discussion.}

The President drew attention to the curious uniformity in the calculated statures of the 18 males and 10 females, as shown in the suspended diagram, ${ }^{1}$ where they were severally represented by vertical lines, marshalled in the order of their lengths. There was only a difference of 3 inches between the stature whose class place was one-quarter of the length of that class, reckoned from its lower end, and the stature whose class place was three-quarters of the length of the class, reckoned also from its lower end. In other words, there was a difference of only 3 inches between the lower and upper quartiles of the class, which is the same thing as twice the "probable error" of the series of recorded statures. He had shown that the difference between the quartiles in any class of English men of the present day, who belonged to the same broad social rank, was $3 \cdot 4$ inches; similarly as regards English women. If modern men and women were mixed together in the above proportions of 18 to 10 , the difference between the quartiles of the mixed series would be much increased; it would

1 A diagram was exhibited in which the statures of 28 individuals (18 male and 10 female) were given as inferred frum the measurement of the long bones of the lower limbs. 
amount to between $4 \frac{1}{4}$ and $4 \frac{1}{2}$ inches. $^{1}$ But the difference between the variability in stature of these ancient races and the modern ones must be greater than is indicated by the above figures of 3 inches for the one and $4 \frac{1}{2}$ for the other, because the statures from which the figure 3 is derived had not been obtained by direct measurement. 'They were inferred from the length of the leg bones, and were therefore "fallible" estimates of the real statures. It would be easy to subtract the effect of this superadded variation, if we knew the "probable error" of this fallible estimate, but it has never yet been determined. It may be that the ancient Britons were more uniform in stature than our modern and greatly mixed races, and again that the statures of the two sexes may have been less different. It may also be that the individuals in the same encampment were closely inter-related and had a family likeness. The facts to be accounted for cannot, however, be strictly ascertained until osteologists shall have determined the "probable error" just alluded to, which would be a matter of little difficulty. It would be advisable to calculate its value in respect to the height of the living man as inferred from the measurement after death, of his femur alone, of his tibia alone, and of the mean of the lengths of his tibia and femur. It would then be easy to calculate the variability of a race from that of the lengths of one or more of the leg bones of many skeletons. This, he need hardly add, is quite another question from that of average stature.

Mr. W. Pengelly remarked that, with the Chairman's permission, he would make a few observations on one or two of the topics which had been so ably placed before the meeting by General Pitt-Rivers.

Oyster shells had been mentioned as occurring among the finds met with by the author, and had thus suggested the question, "Were any other shells found ?" In the most recent deposit in Kent's Cavern, shells of oyster's were abundant, but so also were those of cockles, limpets, and periwinkles, and there were a few examples of Pecten, and of the internal shell of the cuttle-fish (Sepia officinalis).

Shells, however, were found, but less abundantly, in some of the older deposits; thus cockle shells occurred in the granular stalagmitic floor, and in a branch of the cavern, known as the "Wolf's

1 I calculated this value from the data in my table of "Anthropometric Per-centiles," published in the "Journ. Anthrop. Inst.," Vol. XIV, p. 277, and upon the supposition that the proportion between the two sexes was as 20 males to 10 females. In this case the table gives most of the data by inspection, and the rest by interpolation, as follows. The most probable beights for 10 females, taken at hazard. are those of each successive tenth per-centile ; these are printed in my table. Those for 20 males are the values of each successive fifth per('entile. In the table, the 5th and the 95th are giren, leaving the 15th, 25th85 th to be found by interpolation. When this is done, and the 20 males and 10 feinales values are mixed together and then marshalled, it will be found that the value of the 25 th per-centile, or lower quartile, is 6455 inches; and that of the 75th per-centile, or upper quartile, is 68.8 inches. The difference between these is $4: 3$ inches. -F.G. 
Cave," twenty-five shells of the common pecten were found in a cupboard-like recess, between two large masses of limestone, in the still older cave earth. In one instance two, and in another five, of them were found neatly fitted one into another and cemented together with stalagmite. There could be no doubt that a human being had not only packed them, but placed them where they were found. The fact that at least some of them were "dead shells" proved that they were taken to the cavern, certainly in some cases, not because they contained an article of food, but because they were useful as utensils. One or two of them contained traces of charred wood. It would be interesting to know whether General Pitt-Rivers met with any "dead shells" among his finds.

Though the articles found on the existing surface of the immediately adjacent ground were, as the author suggests, probably older then those at the bottom of the pits, it should be borne in mind that breaking the surface was necessarily the earliest work of the excavalors; so that it is neither impossible nor improbable that at this first stage a tool might occasionally be lost, or broken and cast aside, and thus one would not be surprised to find on the surface as it now exists, tools older, and tools more modern, than those found at the bottom of the pits.

Mr. A. L. Lewis having commented upon the exhaustive manner in which General Pitt-Rivers had conducted his investigations, and the beautiful models which showed the results obtained in a manner which would be at once the example and the despair of all future explorers, asked for further information as to the time and manner of the filling up of the pits. He thought the General's statement as to the extent of difference in height brought out by different methods of measurement of bones must lead to uneasy reflections as to the value of some former statistics, and theories based upon those statistics, concerning the early inhabitants of this country. He agreed with Dr. Beddoe that some of the short people in this country (whatever might be the case elsewhere) owed very much of their low stature to an abnormal shortness of the thigh, and that the thigh was an extremely unsafe index of height. It appeared from General Pitt-Rivers' models that some perfect skeletons had been found on his estate: would it not be possible to put some of these skeletons together with leather or india-rubber washers to represent the cartilages, and to measure their actual length? If this were done, and the result compared with that obtained from calculation of the measurement of the thigh-bone, this very important question might perhaps be settled.

The following paper was read by the author :- 